\title{
Haemato-Biochemical Variations in Estuarine Crabs from a Lagoon Ecosystem
}

\author{
1*MORUF, RO; ${ }^{2}$ LAWAL-ARE, AO \\ ${ }^{I}$ Department of Fisheries and Aquaculture, Faculty of Agriculture, Bayero University, Kano, Kano State- Nigeria \\ ${ }^{2}$ Department of Marine Sciences, Faculty of Science, University of Lagos, Akoka, Lagos State- Nigeria \\ *Corresponding author e-mail: tunjimoruf@gmail.com, Phone: +234-8022429983
}

\begin{abstract}
Haematological profiles are often applied as an index of physiological condition of various organisms and thus provide information about the health status of local populations. The haematological and biochemical parameters of the estuarine crabs, Callinectes amnicola, Goniopsis pelii, Sersama huzardii and Uca tangerii from the polluted creek of Lagos Lagoon were examined using standard methods. C. amnicola $(121.7 \pm 0.21)$ were significantly heavier than $G$. pelli $(24 \pm 2.11 \mathrm{~g}), S$. huzardii $(16.15 \pm 15.19 \mathrm{~g})$ and $U$. tangeri $(8.8 \pm 0.5 \mathrm{~g})$. Mean haematological values of the crabs revealed significant variations in total haemocyte count (THC), haemocyte sedimentation rate (HSR) and haemocyte subpopulation. THC in the circulating haemocytes of the crabs was similar for both G. pelli $(2150 \pm 56.69 \mathrm{~mL})$ and $S$. huzardii $(1975.00 \pm 74.46 \mathrm{~mL})$. HSR was lowest in G. pelli $(1.50 \pm 0.71 \mathrm{~mm} / \mathrm{hr})$ and highest in $U$. tangeri $(5.70 \pm 0.82$ $\mathrm{mm} / \mathrm{hr}$ ). Haemocyte sub-population variables showed that eosinophil and basophil did not differ considerably among the crabs. Significant differences were however recorded for granulocyte, agranulocyte and monocyte with $G$. pelli having the highest sub-population of granulocyte $(33.00 \pm 1.41 \%)$ but lowest agranulocyte $(67.00 \pm 1.41 \%)$. Non-significantly higher sub-population of monocytes was recorded for $C$. amnicola $(3.3 \pm 0.03)$. In the mean values of the serum biochemicals, $U$. tangeri showed lowest values for all except aspartate aminotransferase (22.8 U/L) and Urea (32.48 $\mathrm{mg} / \mathrm{dl})$. G. pelli showed highest values for serum protein $(14.36 \mathrm{mg} / \mathrm{dl})$, Globulin $(67.49 \mathrm{mg} / \mathrm{dl})$ and phosphatase alkaline phosphatase (34.50 U/L). The study gave an indication of stress on the health status of the estuarine crabs, hence the need for periodic monitoring of the ecosystem.
\end{abstract}

\section{DOI: https://dx.doi.org/10.4314/jasem.v22i12.5}

Copyright: Copyright $(92018$ Moruf and Lawal-Are. This is an open access article distributed under the Creative Commons Attribution License (CCL), which permits unrestricted use, distribution, and reproduction in any medium, provided the original work is properly cited.

Dates: Received: 24 November 2018; Revised: 20 December 2018; Accepted 22 December 2018

Keywords: Haematology, serum biochemistry, crab, Lagos Lagoon.

Most estuarine crabs are decapod crustaceans of high ecological importance while according to Lawal-Are and Nwankwo (2011), the mangrove estuarine crabs (Sesarmidae) are the dominant species of crabs in the mangrove swamps of Lagos Lagoon. They live beneath drift and high-tide mark in the estuaries and lagoons (Cannicci et. al., 1995). They are amphibious in habit and can be found round intertidal areas with moist/wet muddier regions of the mangrove (Gillikin, 2004). However, some estuarine crabs (Portunidae) inhabit a variety of aquatic habitats from the lower reaches of freshwater rivers, estuaries to coastal marine waters and are highly mobile, making it feasible for them to move between areas and to select habitats (Lawson and Oloko, 2013; Moruf and LawalAre, 2017). Over the years, several studies have emphasized the enormous threats posed to ecological receptors within the lagoon and other interconnected ecosystems (Chukwu, 2006; Usese et al., 2018). Physiological stress response, although initiated as an adaptive response to destabilizing factors, could have damaging effects if prolonged by increasing susceptibility to infections, through immune depression, which caused mortality (Ugwu and Soyinka, 2018). Therefore, there has been a greater understanding of the need to establish reference haematological and biochemical values in crab in order to assess health status and the subsequent diagnosis of disease. Similar literatures on different crab species include Zhou et al. (2000), Amado et al. (2006), Li and Shields (2007), Matozzo and Marin (2010), Adeogun et al. (2015) and Lawal-Are et al. (2018). Hence, the objective of the present study was to examine the haematology and biochemical parameters of Callinectes amnicola, Goniopsi pelli, Sesarma huzardii and Uca tangeri from a tropical polluted creek of Lagos Lagoon.

\section{MATERIALS AND METHODS}

Study site and Sample collection: Samples of $C$. amnicola, G. pelii, S. huzardii and U. tangeri were collected inside and along the mangrove area lining of Lagos Lagoon (Fig. 1), with latitude $6^{\circ} 26^{\prime}-6^{\circ} 37^{\prime} \mathrm{N}$ and longitude $3^{\circ} 23^{\prime}-4^{\circ} 20^{\prime} \mathrm{E}$. It is a typical estuarine water zone with extensive mangrove but low transparency and alkaline $(\mathrm{pH}>7)$ in nature (Moruf and Lawal-Are, 
2015). Samples of the C. amnicola were obtained from fishing trawlers while others were collected by hand picking in hand gloves and transported to the laboratory, acclimatized for 48hrs and fed with sampling location mud rich organic matter until further analysis.

Laboratory procedure: Crab haemolymph was drawn with a $23 \mathrm{G}$ syringe from the juncture between the bases of the ischium of the fifth walking leg. The haemolymph was collected into a syringe flushed with $1 \mathrm{~mL}$ of anticoagulant ( $0.3 \mathrm{M} \mathrm{NaCl}, 0.1 \mathrm{M}$ glucose, 30 $\mathrm{mM}$ Sodium citrate and $26 \mathrm{mM}$ Citric acid), transferred into a $5 \mathrm{~mL}$ lithium heparin bottle kept in an ice chest and haemolymph of crabs were analyzed immediately for haemocyte morphology, haematological and biochemical indices. Haemocyte population parameters were determined immediately after sampling using an improved Neubaeur heamocytometer according to methods described by Blaxhall and Daisley (1973). For the biochemical analysis, haemolymph samples were centrifuged for 10 mins at $5000 \mathrm{~g}$ with a Hawskley micro-haematocrit centrifuge and the serum derived was stored at $-20^{\circ} \mathrm{C}$ for further analysis. The serum was assayed for albumin (ALB), globulin (GLU), aspartate aminotransferase (AST), alanine aminotransferase (ALT) and the phosphatase alkaline phosphatase (ALP) activities according to methods described by Coles (1986).

Data analysis: Data were subjected to single factor ANOVA and Duncan Multiple Range Test (DMRT) for significant differences in means of haematological and serum biochemical parameters between crab species. Differences in means were considered significant when $\mathrm{p}<0.05$.

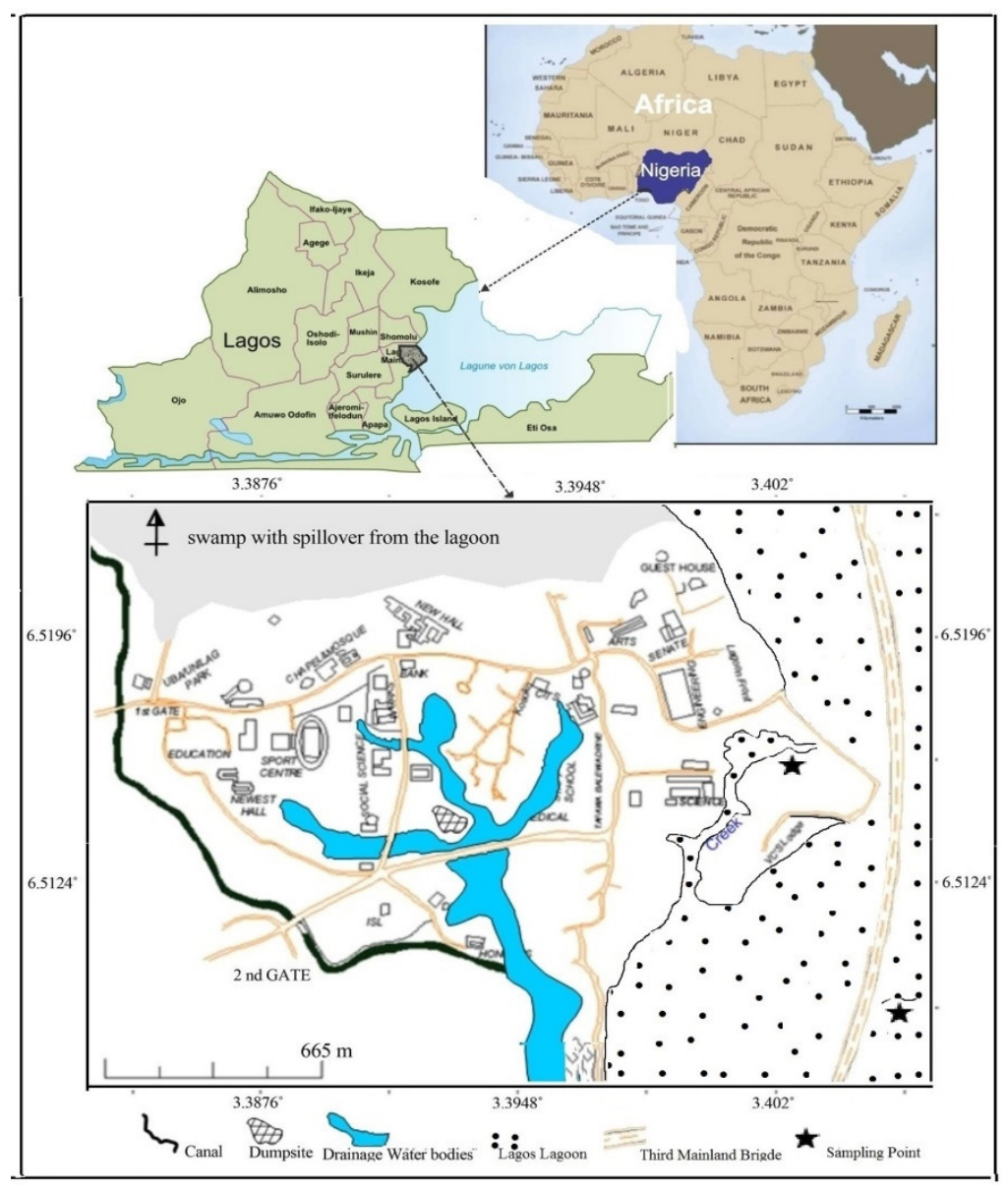

Fig. 1: Map of UNILAG Lagoon Front showing the sampling site Source: Moruf et al. (2018)

\section{RESULTS AND DISCUSION}

Mean values of body weight and haematic indices for the estuarine crabs are given in Table 1. G. pelli $(24 \pm 2.11 \mathrm{~g})$ and $S$. huzardii $(16.15 \pm 15.19 \mathrm{~g})$ were significantly heavier than $U$. tangeri $(8.8 \pm 0.5 \mathrm{~g})$ while C. amnicola $(121.7 \pm 0.21)$ exhibited the highest body weight. Similar sizes have been reported by LawalAre and Nwankwo (2011) and Moruf and Ojetayo (2017) for $S$. huzardii and $U$. tangeri respectively. Haematology result revealed packed cell volume ranging between $2.50 \pm 0.01$ and $4.6 \pm 0.30 \%$. Total haemocyte count (THC) in the circulating haemocytes 
of the crabs was similar for both G. pelli $(2150 \pm 56.69$ $\mathrm{mL})$ and $S$. huzardii $(1975.00 \pm 74.46 \mathrm{~mL})$. The increased THC in the crabs appeared to be associated with lower dissolved oxygen in water. Reports have indicated that the increase in number of circulating haemocytes under hypoxic condition is a compensatory response to maintain oxygen tissue perfusion in crabs (Sussarellu et al., 2012). Lowest haemocyte sedimentation rate (HSR) was observed in G. pelli $(1.50 \pm 0.71 \mathrm{~mm} / \mathrm{hr})$ and highest in $U$. tangeri $(5.70 \pm 0.82 \mathrm{~mm} / \mathrm{hr})$. The higher HSR in $U$. tangeri can be related to inflammatory reactions in tissues leading to faster cell aggreagation or an increase in the percolation of cells. Haemocyte sub-population variables showed that eosinophil and basophil did not differ considerably among the crabs. Significant differences were however recorded for granulocyte, agranulocyte and monocyte with $G$. pelli having the highest sub-population of granulocyte $(33.00 \pm 1.41 \%)$ but lowest agranulocyte $(67.00 \pm 1.41 \%)$. A nonsignificantly highest sub-population of monoocytes was recorded for $C$. amnicola $(3.3 \pm 0.03)$ compared to $S$. huzardii $(2.50 \pm 2.12 \%)$ and $U$. tangeri $(1.00 \pm 0.12$ $\%)$. The significantly higher level of granulocytes in $S$. huzardii and $U$. tangeri may be a stress response to unfavorable environmental conditions. Granulocytes have been reported to play a significant role in the crustacean defense system because of their antibacterial activity and function in secreting extracellular matrix proteins that stops the action of invading organisms, when the host is attacked by either extremely large particles or numerous tiny particles (Chisholm and Smith, 1995). There are similar reports for crayfish (Johansson et al., 1995), Penaeus monodon (Sritunyaluksana et al., 2001) and Litopenaeus vannamei (Liu et al., 2004).

Table 1: Body weight and Haematic Indices of estuarine crabs from a tropical lagoon ecosystem

\begin{tabular}{|c|c|c|c|c|c|}
\hline \multicolumn{2}{|c|}{ Haematic Indices } & C. amnicola & G. pelli & S. huzardii & U. tangeri \\
\hline \multicolumn{2}{|c|}{ Body weight (g) } & $21.7 \pm 0.21^{\mathrm{a}}$ & $24.0 \pm 1.11^{\mathrm{b}}$ & $16.2 \pm 0.19^{b}$ & $8.8 \pm 0.5^{c}$ \\
\hline \multicolumn{2}{|c|}{ Packed Cell Volume (\%) } & $4.6 \pm 0.30^{\mathrm{a}}$ & $2.5 \pm 0.01^{\mathrm{b}}$ & $2.5 \pm 0.21^{\mathrm{b}}$ & $2.8 \pm 0.00^{\mathrm{b}}$ \\
\hline \multicolumn{2}{|c|}{ Total Haemocyte Count (mL) } & $2580 \pm 0.08^{\mathrm{a}}$ & $2150 \pm 0.69^{b}$ & $1975 \pm 0.46^{\mathrm{b}}$ & $1272 \pm 0.10^{\mathrm{c}}$ \\
\hline \multicolumn{2}{|c|}{ Haemocyte Sedimentation Rate $(\mathrm{mm} / \mathrm{hr})$} & $3.4 \pm 0.42^{\mathrm{a}}$ & $1.5 \pm 0.71^{\mathrm{b}}$ & $4.0 \pm 1.41^{\mathrm{a}}$ & $5.7 \pm 0.82^{\mathrm{a}}$ \\
\hline \multirow{5}{*}{$\begin{array}{l}\text { Haemocyte } \\
\text { subpopulation }\end{array}$} & Granulocyte $(\%)$ & $26.78 \pm 0.53^{\mathrm{a}}$ & $33.00 \pm 1.41^{\mathrm{a}}$ & $11.00 \pm 1.41^{\mathrm{b}}$ & $10.00 \pm 5.12^{b}$ \\
\hline & Agranulocyte (\%) & $69.9 \pm 1.23^{\mathrm{a}}$ & $67.0 \pm 1.41^{\mathrm{a}}$ & $86.5 \pm 0.71^{\mathrm{b}}$ & $71.0 \pm 1.23^{\mathrm{b}}$ \\
\hline & Monocyte $(\%)$ & $3.3 \pm 0.03^{\mathrm{a}}$ & $0.00 \pm 0.00^{\mathrm{b}}$ & $2.50 \pm 2.12^{\mathrm{a}}$ & $1.00 \pm 0.12^{\mathrm{a}}$ \\
\hline & Eosino & $0.00 \pm 0.00$ & $0.00 \pm 0.00$ & $0.00 \pm 0.00$ & $0.00 \pm 0.00$ \\
\hline & Basophil (\%) & $0.00 \pm 0.00$ & $0.00 \pm 0.00$ & $0.00 \pm 0.00$ & $0.00 \pm 0.00$ \\
\hline
\end{tabular}

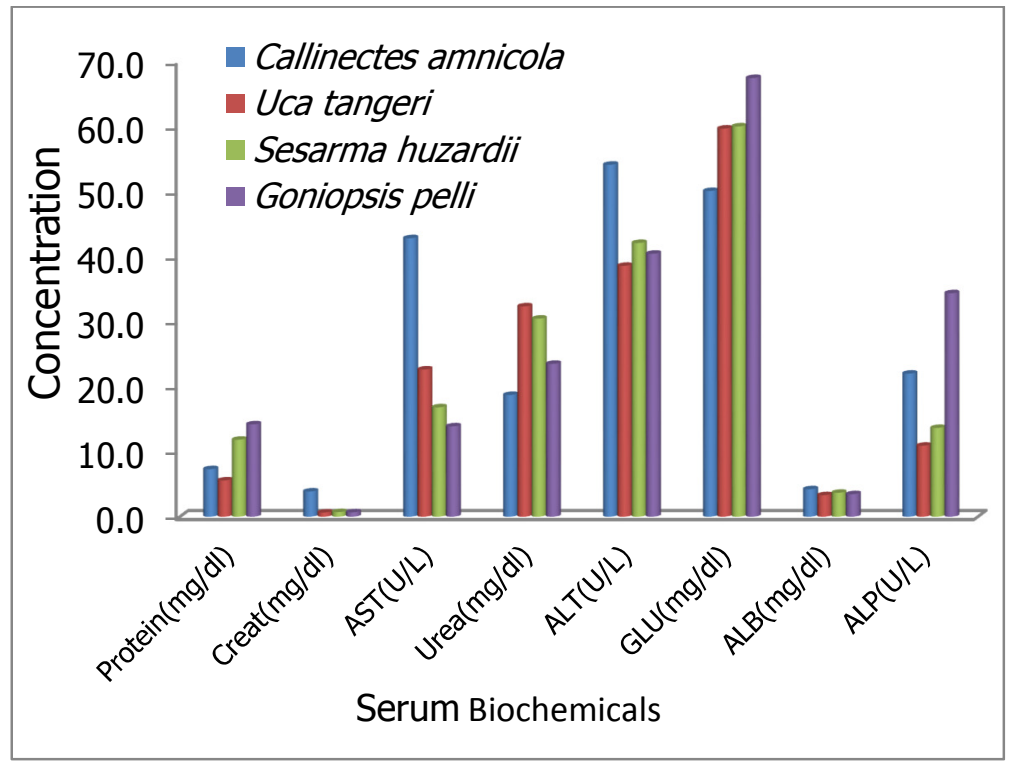

Fig. 2: Serum biochemical profile of estuarine crabs from a tropical lagoon ecosystem

The serum biochemical profile of the estuarine crabs is shown Fig. 2. U. tangeri showed lowest values for all except AST (22.8 U/L) and Urea (32.48 mg/dl). $G$. pelli showed highest values for serum protein 
(14.36mg/dl), Globulin (GLU) (67.49 mg/dl) and phosphatase ALP (34.50 U/L). The total serum protein in these crabs (5.64 -14.36 g/dL) were higher than the range of values reported by Adeogun et al. (2015) in Blue crabs (3.17 $-3.74 \mathrm{~g} / \mathrm{dL})$. The lower concentrations of total serum protein in C. amnicola $(7.4 \mathrm{mg} / \mathrm{dl})$ and $U$. tangeri $(5.6 \mathrm{mg} / \mathrm{dl})$ compared to others may be attributed to increased breakdown of serum peptidic material and modulation of their involvement in various biological processes due to environmental stress. In addition, haemolymph proteins have been reported as evidence of energy reserve in invertebrates, as such lower concentrations may depict lower food availability in a population (Rosas et al., 2012) while higher serum protein concentrations have been associated with higher live wet weight and diet quality (Adeogun et al., 2015). Haematological and biochemical changes in crustaceans are often modulated in response to environmental factors to bring about homeostatic control within the organism and as a result are used as diagnostic tools for assessing the health of wild populations (Velisek et al., 2009).

Conclusion: The studied sites indeed showed signs of environmental stress, which eventually pose devastating effect on the health status of the crab resources. There is therefore the need for periodic monitoring and enforcement of environmental laws. This study has provided valuable baseline data on the haematological and biochemical features of the estuarine crabs in Nigeria.

\section{REFERENCES}

Adeogun, AO; Salami, OA; Chukwuka, AV; Alaka, OO (2015). Haematological and Serum Biochemical Profile of the Blue Crab, Callinectes amnicola from two Tropical Lagoon Ecosystems. Afr. J. Biomed. Res. 18: 233 - 247.

Amado, EM; Freire, CA; Souza, MM (2006). Osmoregulation and tissue water regulation in the freshwater red crab Dilocarcinus pagei (Crustacea, Decapoda), and the effect of waterborne inorganic lead. Aquat. Toxicol. 79: 1-8.

Blaxhall, PC; Daisley, KW (1973). Routine haematological methods for use with fish blood. $J$. Fish Biol. 5: 771-781.

Cannicci, S; Dahdouh-Guebas, F; Anyaona, D; Vannini, M (1995). Homing in the Mangrove Swimming Crab, Thalamita crenata (Decapoda; Portunidae), Ethnol. 100: 424- 452.
Chisolm, LA; Smith, CL (1995). The sea urchin complement homologue, $\mathrm{SpC} 3$, functions as an opsonin. J. Exp Biol. 207: 2147-2155.

Chukwu, LO (2006). Short-term toxicology and accumulation of heavy metals by African giant river prawn, Macrobrachium vollenhoevenii (Herklots, 1857) exposed to treated industrial effluents. Ecol. Environ. Conserv. 12 (1):1-7.

Coles, EH (1986). Veterinary Clinical Pathology. W.B. Saunders, Philadelphia, PA, USA, pp.1-42.

Johansson, MW; Lind, MI; Holmbald, T; Thornqvist, PO; Soderhall, K (1995): Peroxinectin, a novel cell adhesion protein from crayfish blood. Biochem. Biophys. Res. Comm. 216: 1079-1087.

Lawal-Are, A.O; Moruf, RO; Alawode, MM (2018). Haematobiochemial evaluation of mangrove crabs as a biomarker of environmental pollution in a tropical creek.13 th $U N I L A G$ Annual Research Conference and Fair, 2th $-30^{\text {th }}$, August, 2018. $18 \mathrm{SCI} 097$.

Lawal-Are, AO; Nwankwo, H (2011). Biology of the Hairy Mangrove Crab, Sersema Huzardii (Decapoda: Graspidae) from a Tropical Estuarine Lagoon. J. Am. Sci. 7(7): 402-408.

Lawson, EO; Oloko, RT (2013). Growth patterns, Sex ratios and Fecundity estimates in Blue Crab (Callinectes amnicola) from Yewa River, Southwest Nigeria. Adv.in Life Sci. Technol. 7:2433.

Li, C; Shields, JD (2007). Characterization and Primary Culture of Hemocytes from the Blue Crab, Callinectes sapidus. In Cai, S.L. (ed). 5th World Chinese Symposium for Crustaecean Aquaculture. Ocean Press, Beijing, China. Tran. Chinese Crusta. Soc. 5: 25-35.

Liu, CH; Cheng, W; Kuo, CM; Chen, JC (2004). Molecular cloning and characterization of a cell adhesion molecule, Peroxinectin from the white shrimp Litopenaeus vannamei. Fish Shellfish Immunol. 17: 13-26.

Matozzo, V; Martin, MG (2010). First cytochemical study of haemocytes from the crab Carcinus aestuarii (Crustaecean:Decapoda). Eur. J. Histochem. 54 (1): 44-49.

Moruf, RO; Bolaji, OD; Lawal-Are, AO (2018). Biometrics, gut contents and sexual dimorphism of 
the West African Mud Creeper, Tympanotonus fuscatus var radula (Linnaeus, 1758) from the mangrove swamps of a coastal estuary in Nigeria. Egypt. J. Aquat. Biol. Fish. 22(1): 87- 96.

Moruf, RO; Lawal-Are, AO (2015). Growth pattern, whorl and girth relationship of the Periwinkle, Tympanotonus fuscatus var radula (Linnaeus, 1758) from a tropical estuarine lagoon, Lagos, Nigeria. Inter. J. Fish. Aquat. Stud. 3(1): 111-115.

Moruf, RO; Lawal-Are, AO (2017). Size composition, Growth pattern and Condition factor of two Portunid crabs, Callinectes amnicola (De Rochebrune) and Portunus validus (Herklots) from Lagos Coast, Nigeria. Nig. J. Fish. Aqua. 5(1): 15 -21 .

Moruf, RO; Ojetayo, TA (2017). Biology of the West African fiddler crab, Uca tangeri (Eydoux, 1835) (Decapoda: Ocypodidae) from a mangrove wetland in Lagos, Nigeria. Inter. J. Aquat. Biol. 5 (4): 263-267.

Rosa, RD; De Lorgeril, J; Tailliez, P; Bruno, R; Piquemal, D; Bachère, E (2012). A hemocyte gene expression signature correlated with predictive capacity of oysters to survive Vibrio infections. BMC genomics 13(1): 252.

Sritunyalucksana, K; Wongsuebsantati, K; Johansson, MW; Söderhäll, K (2001). Peroxinectin, a cell adhesive protein associated with the proPO system for the black tiger shrimp, Penaeus monodon. Dev. Comp. Immunol. 25:353-363.
Sussarellu, R; Fabioux, C; Camacho S.M; Le Goïc, N; Lambert, C; Soudant, P; Moraga, D (2012). Molecular and cellular response to short-term oxygen variations in the Pacific oyster Crassostrea gigas. J. Exp. Mar. Biol. Ecol. 412: 87-95.

Ugwu, GC; Soyinka, OO (2018). Evaluation of the haematology and biochemistry of the silver catfish, Chrysichthys nigrodigitatus as biomarker of environmental pollution in a tropical lagoon. Aceh J. Anim. Sci. 3 (1): 10-16.

Usese, AI; Lawal-Are, AO; Moruf, RO; Chukwu, LO (2018). Biomarker Responses to Environmental Stressors in the Hairy Mangrove Crab, Sesarma huzardii (Graspidae) from a Tropical Lagoon Mudflat in Nigeria. Alexandria J. Vet. Sci. 57 (1): 4-10.

Velisek, J; Svobodova, Z; Piackova, V; Sudova, E (2009). Effects of acute exposure to metribuzin on some hematological, biochemical and histopathological parameters of common carp (Cyprinus carpio L.). Bull. Environ. Contam. Toxicol. 82: 492-495.

Zhou, XW; Chen, QX; Chen, Z; He, ZQ; Zhou, HM (2000). Effects of oxodiperoxovanadate (V) complexes on the activity of green crab (Scylla serrata) alkaline phosphatase. Biochem. 65 (12); 1424-1428. 